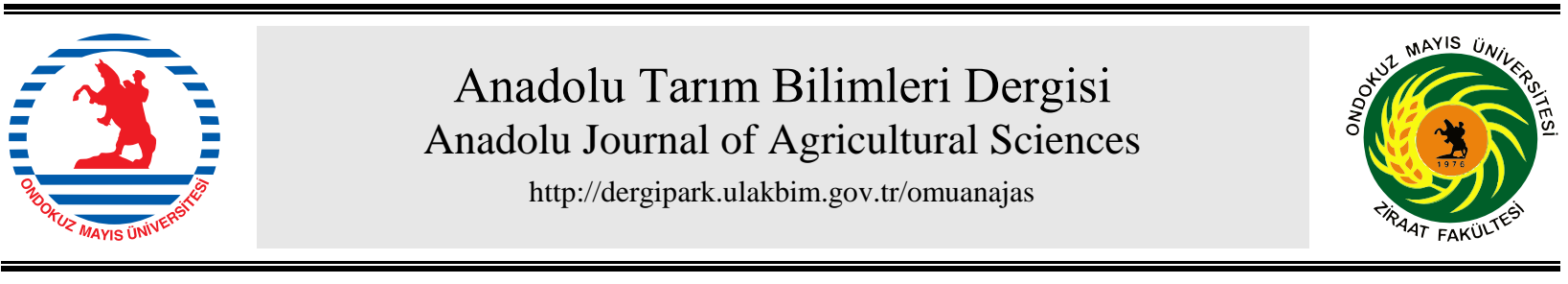

Araştırma/Research

Anadolu Tarım Bilim. Derg./Anadolu J Agr Sci, 31 (2016) ISSN: 1308-8750 (Print) 1308-8769 (Online) doi: 10.7161/omuanajas.269982

\title{
Iğdır ilinden seçilen ceviz (Juglans regia L.) genotiplerinin bazı pomolojik ve kimyasal özellikleri
}

\author{
Ersin Gülsoy ${ }^{a}$, Tuncay Kaya ${ }^{a}$, Mücahit Pehluvan ${ }^{a}$, Mikdat Şimşek $^{b}$ \\ ${ }^{a}$ Iğdır Üniversitesi, Ziraat Fakültesi, Bahçe Bitkileri Bölümü, Iğdır, Türkiye \\ ${ }^{b}$ Dicle Üniversitesi, Ziraat Fakültesi, Bahçe Bitkileri Bölümü, Diyarbakır, Türkiye \\ *Sorumlu yazar/corresponding author: ersin.gulsoy@igdir.edu.tr
}

Geliş/Received 24/03/2016 Kabul/Accepted 25/05/2016

\begin{abstract}
ÖZET
$\mathrm{Bu}$ çalışma 2013 ve 2014 yıllarında Iğdır ilinde tohumdan yetişmiş 16 adet ceviz genotipin pomolojik özellikleri, kimyasal ve mineral içeriklerini belirlemek amacıyla yürütülmüştür. Selekte edilen ceviz genotiplerinin pomolojik özelliklerinden kabuklu meyve ağırlığı, iç ağırlığı ve iç oranı sırasıyla 10.80$15.77 \mathrm{~g}, 5.15-7.46 \mathrm{~g}$ ile \%42.87-58.35 arasında değişmiştir. Seçilen genotiplerin yağ, protein, kül ve nem içerikleri ise sirasıyla \%50.03-64.98, \%10.23-22.14, \%0.97-3.96 ve \%3.05-4.48 arasında değişmiştir. Ayrıca, bu genotiplerin mineral madde içerikleri ortalama olarak \%2.11 N, $314.69 \mathrm{mg}$

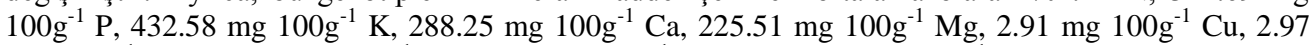

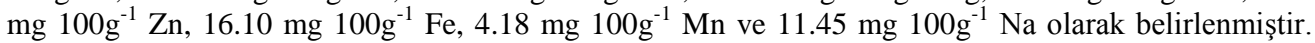
Ümitvar genotiplerde azot $(\mathrm{N})$ içeriği diğer minerallere kıyasla daha yüksek bulunmuştur. Bunu sirasiyla Potasyum (K), Fosfor (P), Kalsiyum (Ca), Magnezyum (Mg), Demir (Fe), Sodyum (Na), Mangan (Mn), Çinko $(\mathrm{Zn})$ ve Bakır $(\mathrm{Cu})$ takip etmiştir.
\end{abstract}

Some pomological properties and chemical contents of selected walnut (Juglans regia L.) genotypes from Iğdır province

\section{ABSTRACT}

This study was conducted on 16 walnut genotypes grown from seed to determine some pomological, chemical properties and mineral content in Iğdır province in the years of 2013 and 2014. Fruit weight, kernel weight and kernel ratio of selected walnut genotypes as pomological properties ranged between 10.80-15.77 g, 5.15-7.46 g and 42.87-58.35\%, respectivelity. Chemical properites of selected genotypes such as fat, protein, ash and moisture content varied from 50.03 to $64.98 \%, 10.23$ to $22.14 \%, 0.97$ to $3.96 \%$ and 3.05 to $4.48 \%$, respectively. Additionally, the mineral contents of these genotypes contained

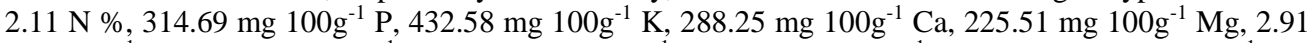

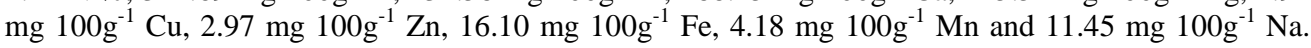
The nitrogen $(\mathrm{N})$ content in promising genotypes was found higher than those of the other mineral contents. This was followed by Potassium (K), Phosphorus (P), Calcium (Ca), Magnesium (Mg), İron $(\mathrm{Fe})$, Sodium $(\mathrm{Na})$, Manganese $(\mathrm{Mn})$, Zinc $(\mathrm{Zn})$ and Copper $(\mathrm{Cu})$, respectively.
Anahtar Sözcükler: Ceviz Iğdır Kimyasal içerikler Pomolojik özellikler

\section{Giris}

Ceviz (Juglans regia L.) ülkemizde doğal olarak yetişen meyvesi, kerestesi, yaprağı ve yeşil kabukları değerlendirilebilen sert kabuklu bir meyve türüdür. Türkiye, ceviz bitkisinin anavatanı olan ülkelerinden biridir (Kapluhan, 2015).

Dünya'da ceviz üretimi yapılan en önemli ülkelerden biri de Türkiye'dir. 2012 y1lı verilerine göre dünya ceviz üretimi 3.420 .571 ton'dur. Çin, İran ve $\mathrm{ABD}$ ilk üç sırayı paylaşan ülkeler olup bu ülkelerin ceviz üretimi surasiyla $1.700 .000,450.000$ ve 425.820 tondur. Türkiye ise 194.298 tonluk üretimi ile 4. sirada yer almaktadır (FAO, 2012). Bu üretim son yllara kadar çoğunlukla tohumla yetiştirilen ceviz ağaçlarından elde edilmiştir. Ancak, son zamanlarda seleksiyon yoluyla elde edilip çeşit özelliği kazanan ceviz çeşitlerinin yanı sıra yabancı ceviz çeşitleriyle de üretim giderek yaygınlaşmaktadır (Koyuncu ve ark., 2004; Dogan ve Akgul, 2005; Simsek ve ark., 2010a).

Türk Standartları Enstitüsü tarafindan ceviz çeşitlerinde bir kalite kriteri olarak bazı pomolojik 
özellikler tanımlanmıştır (Anonim, 1990, 1991). Bu özellikler arasında meyve çapı $(24-28 \mathrm{~mm})$, taze ve kurutulmuş meyvede nem içeriği yer almaktadır.

Sağlıklı yaşam açısından birçok faydası ve rolü bulunan önemli besinlerden biri de cevizdir (Şen ve Karadeniz, 2015). Ceviz, yüksek oranda yağ ve protein içermesinin yanı sıra potasyum, fosfor, bakır, çinko, demir, kalsiyum, magnezyum, mangan ve sodyum gibi mineralleri de yüksek oranda içermektedir. $\mathrm{Bu}$ mineraller insan kanında iyi kolesterol olarak bilinen HDL düzeyini yükseltici, buna karşın kötü kolesterol olarak bilinen LDL düzeyini düşürücü (Davis ve ark., 2007), atardamar fonksiyonunu iyileştirici (Ros ve ark., 2004), iltihaplanmayı azaltıcı (Tapsell ve ark., 2004) ve koroner kalp krizi riskini azaltıcı (Bloomhoff ve ark., 2006) fonksiyona sahiptir. Bu sebeple, ceviz diyet programları içerisinde tüketilmesi gereken besinler arasında önerilmektedir (Şahin, 2005; Vinson ve Cai, 2011). Bu meyve türündeki besin değerinin yüksek olması sebebiyle vejeteryan beslenmede de önemi büyüktür (Şen, 1986).

Günümüze kadar ülkemizin değişik yörelerinde ceviz genotiplerin pomolojik özellikleri, mineral ve veya kimyasal bileşimlerin belirlenmesi üzerine Aşkın ve Gün, (1995); Koyuncu ve Aşkın, (1995); Koyuncu ve Askin, 1999; Koyuncu ve ark., 2004; Ünver ve Çelik, 2005; Ozkan ve Koyuncu, 2005; Oğuz ve Aşkın, 2007; Kazankaya ve ark., 2008; Bakkalbaşı ve ark., 2010; Muratoğlu ve Balta, 2010; Simsek, 2010b, Simsek, 2010c; Polat ve ark.,(2015) gibi araştırıcılar tarafından oldukça fazla çalışma yapılmıştır.

Ancak, önemli tarım bölgelerimizden olan Iğdır yöresinde yetişen ceviz genotiplerinin pomolojik, mineral ve kimyasal bileşenleri konusunda hiçbir çalışma yapılmamıştır. $\mathrm{Bu}$ nedenle, Iğdır yöresi seleksiyonu neticesinde belirlenen ceviz genotiplerinin ele alındığı bu çalışmada bu genotiplerin bazı pomolojik ve kimyasal özellikleri ile mineral madde içeriklerinin belirlenmesi amaçlanmıştır.

\section{Materyal ve Yöntem}

\subsection{Materyal}

$\mathrm{Bu}$ çalışmanın materyalini, 2013-2014 yıllarında Doğu Anadolu'da bulunan Iğdır merkez ilçesi ve bağlı köylerinde gerçekleştirilen seleksiyon çalışması neticesinde 103 genotip arasından seçilen 16 ceviz genotipi oluşturmaktadır.

\subsection{Yöntem}

Pomolojik özellikler: Meyve ölçümleri, kabuklu ve iç ceviz özelliklerinin belirlenmesi Şen (1980)'e göre gerçekleştirilmiş ve bu özelliklerin belirlenmesinde 3 yinelemeli ve her yinelemede 10 adet meyve kullanılmıştır Seçilen genotiplerin kabuklu meyve ağırlığı (g), iç ağırlığı (g) ve iç oranı (\%) incelenmiştir. Kabuklu ve iç meyve boyutlarına ait ölçümler $0.01 \mathrm{~mm}$ ye duyarlı dijital kumpas ile ağırlık tartımları ise $0.01 \mathrm{~g}$ hassasiyetli elektronik terazide yapılmıştır (Şen, 1980; Korac ve ark., 1988; Yarılgaç, 1997; Simsek, 2010b)

Kimyasal içerikler: Ceviz genotiplerin nem içeriği darası alınmış $3 \mathrm{~g}$ iç ceviz örneğinin $105^{\circ} \mathrm{C}$ 'de etüvde kurutulmasıyla \% olarak hesaplanmıştır (Cemeroğlu, 2010). Toplam yağ miktarı Soxholet Metoduna göre (James, 1995); protein miktarı Mikro-Kjeldahl yöntemine göre (Nx6.25) (Kacar, 1984) belirlenmiştir. Kül miktarı porselen krozelere 1'er g tartılan ve 105 ${ }^{0} \mathrm{C}^{\prime}$ de 24 saat tutulan örneklerin $200{ }^{0} \mathrm{C}^{\prime}$ ye ayarlı kurutma dolabinda 24 saat bekletilmesi ve daha sonra $560{ }^{0} \mathrm{C}^{\prime}$ ye ayarlı kül firınında 10 saat süreyle yakılmasıly bulunmuştur (Gönül ve ark., 1988). Ceviz örneklerinin toplam azot miktarı kjeldahl yöntemiyle belirlenmiş̧ir. Mineral elementler belirlenirken ceviz örnekleri $500{ }^{\circ} \mathrm{C}$ 'de yakılarak üzerlerine $4 \mathrm{ml} 3 \mathrm{~N}$ HCL solüsyonu eklenmiş (Kacar, 1972) ve bu solüsyon atomik absorbsiyon cihazına enjekte edilmiş̦tir (Varian Techtron Model AAS 1000, Varian Associates, Palo Alto, CA). Mineral elementler (P, K, Cu, Zn, Fe, Ca, $\mathrm{Mg}, \mathrm{Mn}$ ve $\mathrm{Na}$ ) atomik absorbsiyon cihazındaki farklı lambalar kullanılarak tespit edilmiştir. Mineral element içeriklerine ait okumalarda azot \% olarak, diğer elementler ise $\mathrm{mg} / 100 \mathrm{~g}$ olarak ifade edilmiştir.

\section{Bulgular ve Tartışma}

2013-2014 yılları arasında Iğdır yöresinde gerçekleştirilen seleksiyon çalışmasında 16 ceviz genotipi seçilmiştir. Bu genotiplerin iki yıllık ortalama verilerine göre meyve ağırlığı $10.80 \mathrm{~g}$ (76-IĞD-17)15.77 g (76-IĞD-65), iç ağırlığı 5.15 g (76-IĞD-17)7.46 g (76-IĞD-31), iç oranı \%42.87 (76-IĞD-65)\%58.35 (76-IĞD-39) arasında değişmiştir (Çizelge 1).

Elde edilen sonuçlar daha önce yapılan bazı araştırmaların (Yarılgaç, 1997; Oğuz ve Aşkın, 2007; Şimşek ve Osmanoğlu, 2010; Keleş, 2012) sonuçları ile paralel olmuştur. Ümitvar ceviz genotiplerinin belirlenmesi amaciyla yürütülen seleksiyon çalışmalarında Gevaş yöresinde ümitvar ceviz genotiplerinin meyve ağırlıkları 11.2-16.8 g, iç ağırlıkları 5.8-7.5 g, iç oranları \% 41.1-53.1 (Yarılgaç, 1997); Ermenek yöresi ceviz seleksiyonunda meyve ağılıkları 10.45-15.88 g, iç ağırlıkları 5.26-6.93 g, iç oranları \%41.05-50.33 (Oğuz ve Aşkın, 2007); Mazıdağı (Mardin) yöresi ceviz seleksiyonunda meyve ağırlıkları 10.28-14.55g, iç ağırlıkları 5.55-7.22 $\mathrm{g}$ ve iç oranlar1 \%43.58-63.10 (Şimşek ve Osmanoğlu, 2010); Gümüşhacıköy seleksiyonunda meyve ağırlığı 8.93$13.82 \mathrm{~g}$, iç ağıllığ $4.62-7.36 \mathrm{~g}$ ve iç oran $\% 47.80-58.98$ arasında (Keleş, 2012) bulunmuştur. Ceviz genotip ve çeşitlerinin pomolojik özellikler bakımından çalışmaların sonuçları ile benzerlik veya farklılıklar göstermesinin nedeni, genetik yapıya bağlı olabildiği gibi, ekolojik ve bakım koşullarından da kaynaklanabilir

Seçilen 16 ümitvar genotipin; toplam yağ içeriği \% 50.03 (76-IĞD-59) ile \%64.98 (76-IĞD-4), protein içeriği \%10.23 (76-IĞD-65) ile \%22.14 (76-IĞD-59), 
Çizelge 1. Ümitvar genotiplerin bazı pomolojik ve kimyasal özellikleri

\begin{tabular}{llllllll}
\hline $\begin{array}{l}\text { Genotip } \\
\text { No }\end{array}$ & $\begin{array}{l}\text { Meyve ağırlığı } \\
(\mathrm{g})\end{array}$ & $\begin{array}{l}\text { İç ağırlığı } \\
(\mathrm{g})\end{array}$ & $\begin{array}{l}\text { İç oran1 } \\
(\%)\end{array}$ & $\begin{array}{l}\text { Yağ } \\
(\%)\end{array}$ & $\begin{array}{l}\text { Protein } \\
(\%)\end{array}$ & $\begin{array}{l}\text { Kül } \\
(\%)\end{array}$ & $\begin{array}{l}\text { Nem } \\
(\%)\end{array}$ \\
\hline 76- IĞD-3 & 11.87 & 6.57 & 52.10 & 59.46 & 19.23 & 2.00 & 4.43 \\
76- IĞD-4 & 11.60 & 6.37 & 54.91 & 64.98 & 21.03 & 0.97 & 3.32 \\
76- IĞD-10 & 12.82 & 6.46 & 47.73 & 63.99 & 18.84 & 3.00 & 3.90 \\
76-IĞD-17 & 10.80 & 5.15 & 50.29 & 52.97 & 11.39 & 2.00 & 3.89 \\
76-IĞD-27 & 13.04 & 6.95 & 53.28 & 51.83 & 18.85 & 2.00 & 3.05 \\
76-IĞD-31 & 14.24 & 7.46 & 50.76 & 53.71 & 16.00 & 1.00 & 3.40 \\
76-IĞD-32 & 11.69 & 6.22 & 53.27 & 61.90 & 15.10 & 3.00 & 3.64 \\
76-IĞD-37 & 13.07 & 6.23 & 46.46 & 60.87 & 20.45 & 0.99 & 4.35 \\
76-IĞD-39 & 11.75 & 6.86 & 58.35 & 59.72 & 11.83 & 1.98 & 3.40 \\
76-IĞD-48 & 12.14 & 6.02 & 46.50 & 64.74 & 19.68 & 1.00 & 3.49 \\
76-IĞD-59 & 12.05 & 6.86 & 55.22 & 50.03 & 22.14 & 1.94 & 3.64 \\
76-IĞD-65 & 15.77 & 6.76 & 42.87 & 58.44 & 10.23 & 1.96 & 3.51 \\
76-IĞD-72 & 14.20 & 6.84 & 46.95 & 54.06 & 12.05 & 3.00 & 3.84 \\
76-IĞD-76 & 13.91 & 6.52 & 47.51 & 60.38 & 15.06 & 3.96 & 3.79 \\
76-IĞD-88 & 12.51 & 6.03 & 48.15 & 51.32 & 14.64 & 2.00 & 3.13 \\
76-IĞD-91 & 14.88 & 6.41 & 43.06 & 51.53 & 14.11 & 1.96 & 4.48 \\
\hline Ortalama & 12.90 & 6.48 & 49.84 & 57.50 & 16.29 & 2.05 & 3.70 \\
Minimum & 10.80 & 5.15 & 42.87 & 50.03 & 10.23 & 0.97 & 3.05 \\
Maksimum & 15.77 & 7.46 & 58.35 & 64.98 & 22.14 & 3.96 & 4.48 \\
\hline
\end{tabular}

nem içeriği \%3.05 (76-IĞD-27) ile \%4.48 (76-IĞD-91) kül içeriği \%0.97 (76-IĞD-4) ile \%3.96 (76-IĞD-76) arasında değişmiştir (Çizelge 1).

Gerek ülkemizde ve gerekse yurt dişında cevizin kimyasal bileşenlerinin belirlenmesi üzerine çalışmalar yürütülmüsstür. Bu bağlamda Mitrovic ve ark. (1988) Yugoslavya'daki ceviz seleksiyonu çalışmasından seçtikleri ve tescil ettikleri 14 ceviz çeşidinin yağ oranlarını \%58.0-75.2 ve protein oranlarını ise \% 10.023.43; Andrienko ve Zatokovay (1990) Ukrayna'da yaptıkları ceviz seleksiyonu çalışmasında yağ oranını $\%$ 68.1-71.3, protein oranın \% 17.8-19.2; Sharma ve Sharma (2004), Hindistan'in Himachal Pradesh bölgesinde ceviz konusunda yürüttükleri bir çalışmada yağ oranının \%40.85-70.40 ve protein oranının ise \% 8.16-16.92 arasında değiştiğini bildirmişlerdir.

Koyuncu ve ark. (2002) Van ili ve Bahçesaray ilçesinden seçilen 20 adet ceviz tipi üzerinde yaptıkları araştırmada yă oranınının \%62.08-70.16, protein içeriğinin \%12.87-18.97, nem miktarının \%2.13-3.59 ve kül miktarının \%0.84-2.12 arasında değiştiğini belirtmişlerdir.

Gevaş yöresinden seçilen ceviz genotiplerinde yă oranlar1 \%54.89 ile $\% 68.20$, protein oranlar1 $\% 12.11$ ile $\% 23.43$, kül oranları ise \%1.62 ile \%3.21 (Yarılgaç ve ark., 2003); Tavas yöresinden seçilen ceviz genotiplerinde \%62.02-71.56 yağ, \%11.31-17.69 protein (Çelik ve ark., 2011); Ahlat yöresinden seçilen ceviz genotiplerinde \%51.5-62.8 yağ, \%15.5-23.3 protein, \%2.2-4.2 kül ve \%1.0-2.4 nem (Muradoğlu ve Balta, 2010); Erzincan yöresinden seçilen ceviz genotiplerinde protein oran $1 \% 13.74-22.34$, yağ oran $1 \% 48.97-66.45$ ve kül oranı ise \%1.69-2.24 (Özrenk ve ark., 2005) arasında kaydedilmiştir.

Cevizin genotiplerinin bazı kimyasal içerikleri ile ilgili yapılan bu çalışmanın sonuçları önceki çalışmaların bulguları ile benzer bulunmuştur (Mitrovic ve ark., 1988; Andrienko ve Zatokovay, 1990; Sharma ve Sharma, 2004; Yarılgaç ve ark., 2003; Çelik ve ark., 2011; Muradoğlu ve Balta, 2010; Özrenk ve ark., 2005). Ancak, cevizin kimyasal içerikleri konusunda elde edilen bir kısım sonuçların farklılık göstermesinin nedeni genetik yapıya, ekolojik ve bakım koşulları ile hasat zamanına bağlı olarak değişiklik gösterebilir.

$\mathrm{Bu}$ çalışmada, seçilen 16 ceviz genotipin mineral element içerikleri ortalama olarak \%2.11 N, $314.69 \mathrm{mg}$ P, $432.58 \mathrm{mg} \mathrm{K}, 2.91 \mathrm{mg} \mathrm{Cu}, 2.97 \mathrm{mg} \mathrm{Zn,} 16.10 \mathrm{mg} \mathrm{Fe}$, $288.25 \mathrm{mg} \mathrm{Ca}, 225.51 \mathrm{mg} \mathrm{Mg}, 4.18 \mathrm{mg} \mathrm{Mn}$ ve 11.45 $\mathrm{mg} \mathrm{Na}$ bulunmuştur (Çizelge 2). Ceviz genotip ve çeşitlerinin mineral madde içerikleri konusunda pek çok araştırma yapılmıştır. Akça (2001), $100 \mathrm{~g}$ yenilebilir iç cevizde yaklaşık $89.0 \mathrm{mg} \mathrm{Ca}, 1.30 \mathrm{mg} \mathrm{Cu}, 2.40 \mathrm{mg} \mathrm{Fe}$, $113.0 \mathrm{mg} \mathrm{Mg}, 2.10 \mathrm{mg} \mathrm{Mn}, 348.0 \mathrm{mg} \mathrm{P,} 391.0 \mathrm{mg} \mathrm{K}$ ve $2.90 \mathrm{mg} \mathrm{Zn}$ bulunduğunu belirtmektedir. Tapia ve ark. (2013) tarafindan İspanya'nın güneybatı bölgesinde farklı bahçelerde yetişen dört farklı ceviz çeşidi 
Çizelge 2. Ümitvar genotiplerin makro-mikro element içerikleri (100 gram iç meyvede)

\begin{tabular}{lllllllllll}
\hline $\begin{array}{l}\text { Genotip } \\
\text { No }\end{array}$ & $\begin{array}{l}\mathrm{N} \\
(\%)\end{array}$ & $\begin{array}{l}\mathrm{P} \\
(\mathrm{mg})\end{array}$ & $\begin{array}{l}\mathrm{K} \\
(\mathrm{mg})\end{array}$ & $\begin{array}{l}\mathrm{Ca} \\
(\mathrm{mg})\end{array}$ & $\begin{array}{l}\mathrm{Mg} \\
(\mathrm{mg})\end{array}$ & $\begin{array}{l}\mathrm{Na} \\
(\mathrm{mg})\end{array}$ & $\begin{array}{l}\mathrm{Fe} \\
(\mathrm{mg})\end{array}$ & $\begin{array}{l}\mathrm{Cu} \\
(\mathrm{mg})\end{array}$ & $\begin{array}{l}\mathrm{Zn} \\
(\mathrm{mg})\end{array}$ & $\begin{array}{l}\mathrm{Mn} \\
(\mathrm{mg})\end{array}$ \\
\hline 76- IĞD-3 & 2.65 & 221.74 & 325.96 & 187.92 & 171.63 & 11.63 & 10.40 & 2.28 & 1.78 & 1.36 \\
76-IĞD-4 & 2.25 & 346.79 & 403.94 & 252.04 & 294.71 & 12.16 & 19.82 & 3.25 & 4.00 & 2.74 \\
76-IĞD-10 & 2.38 & 411.20 & 498.31 & 152.60 & 270.15 & 18.94 & 24.40 & 2.91 & 3.32 & 4.07 \\
76-IĞD-17 & 1.54 & 332.01 & 458.60 & 309.82 & 270.79 & 8.17 & 11.07 & 2.48 & 1.81 & 1.31 \\
76-IĞD-27 & 2.92 & 260.42 & 422.36 & 375.10 & 114.04 & 8.87 & 10.93 & 2.39 & 2.46 & 5.24 \\
76-IĞD-31 & 2.58 & 312.58 & 447.90 & 395.60 & 233.15 & 6.98 & 16.14 & 3.15 & 3.37 & 4.70 \\
76-IĞD-32 & 2.11 & 408.85 & 481.99 & 293.30 & 223.98 & 12.76 & 16.46 & 3.41 & 3.13 & 6.65 \\
76-IĞD-37 & 1.56 & 311.12 & 430.48 & 305.71 & 253.13 & 8.57 & 11.70 & 2.71 & 1.97 & 3.21 \\
76-IĞD-39 & 2.05 & 206.48 & 310.16 & 232.40 & 55.16 & 7.50 & 7.91 & 2.35 & 1.95 & 2.73 \\
76-IĞD-48 & 1.37 & 383.02 & 437.35 & 330.80 & 237.52 & 13.14 & 21.68 & 3.17 & 3.62 & 4.40 \\
76-IĞD-59 & 2.53 & 376.43 & 427.93 & 312.62 & 290.97 & 12.31 & 17.12 & 3.45 & 4.12 & 4.63 \\
76-IĞD-65 & 1.97 & 336.38 & 452.14 & 301.96 & 263.09 & 13.62 & 19.08 & 3.04 & 3.58 & 4.72 \\
76-IĞD-72 & 1.51 & 329.02 & 445.75 & 314.90 & 248.74 & 21.76 & 27.29 & 3.02 & 3.42 & 4.54 \\
76-IĞD-76 & 2.44 & 253.70 & 429.54 & 332.87 & 246.61 & 4.57 & 15.01 & 3.13 & 3.55 & 9.63 \\
76-IĞD-88 & 1.75 & 296.15 & 458.74 & 313.60 & 234.95 & 9.82 & 16.59 & 3.31 & 3.49 & 4.62 \\
76-IĞD-91 & 2.22 & 249.10 & 490.07 & 200.78 & 199.52 & 12.37 & 11.96 & 2.45 & 1.97 & 2.39 \\
\hline Ortalama & 2.11 & 314.69 & 432.58 & 288.25 & 225.51 & 11.45 & 16.10 & 2.91 & 2.97 & 4.18 \\
Minimum & 1.37 & 206.48 & 310.16 & 152.60 & 55.16 & 4.57 & 7.91 & 2.28 & 1.78 & 1.31 \\
Maksimum & 2.92 & 411.20 & 498.31 & 395.60 & 294.71 & 21.76 & 27.29 & 3.45 & 4.12 & 9.63 \\
\hline
\end{tabular}

üzerinde yaptıkları araştırmada, Serr çeşidinde $1.67 \mathrm{mg}$ $\mathrm{Zn}, 1.47 \mathrm{mg} \mathrm{Cu}, 2.2 \mathrm{mg} \mathrm{Mn}, 2.1 \mathrm{mg} \mathrm{Fe}, 419 \mathrm{mg} \mathrm{Mg}$, $133 \mathrm{mg} \mathrm{Ca}, 4.8 \mathrm{mg}$ Na ve $370 \mathrm{mg} \mathrm{K}$; Hartley çeşidinde $1.82 \mathrm{mg} \mathrm{Zn}, 1.49 \mathrm{mg} \mathrm{Cu}, 3 \mathrm{mg} \mathrm{Mn}, 1.5 \mathrm{mg} \mathrm{Fe}, 443 \mathrm{mg}$ $\mathrm{Mg}, 135 \mathrm{mg} \mathrm{Ca}, 2 \mathrm{mg} \mathrm{Na}$ ve $350 \mathrm{mg} \mathrm{K}$; Chandler çeşidinde $1.90 \mathrm{mg} \mathrm{Zn,} 1.12 \mathrm{mg} \mathrm{Cu}, 2.44 \mathrm{mg} \mathrm{Mn}, 1.6 \mathrm{mg}$ $\mathrm{Fe}, 415 \mathrm{mg} \mathrm{Mg}, 94 \mathrm{mg} \mathrm{Ca}, 1.6 \mathrm{mg} \mathrm{Na}$ ve $300 \mathrm{mg} \mathrm{K}$ ve Howard çeşidinde ise $1.95 \mathrm{mg} \mathrm{Zn}, 0.72 \mathrm{mg} \mathrm{Cu}, 2.03 \mathrm{mg}$ $\mathrm{Mn}, 1.9 \mathrm{mg} \mathrm{Fe}, 3.81 \mathrm{mg} \mathrm{Mg}, 83 \mathrm{mg} \mathrm{Ca}, 4.5 \mathrm{mg} \mathrm{Na}$ ve $370 \mathrm{mg} \mathrm{K}$ tespit etmişlerdir.

Muradoğlu ve ark. (2011) Bingöl'de yaptıkları bir araştırmada seçtikleri ceviz genotiplerin iç meyvelerindeki mineral madde içeriklerinin ortalama

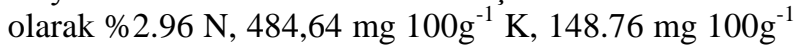
$\mathrm{Ca} ; 166.75 \mathrm{mg} 100 \mathrm{~g}^{-1} \mathrm{Mg} ; 3.41 \mathrm{mg} 100 \mathrm{~g}^{-1} \mathrm{Fe}, 1.93 \mathrm{mg}$ $100 \mathrm{~g}^{-1} \mathrm{Mn}, 1.27 \mathrm{mg}^{100 \mathrm{~g}^{-1}} \mathrm{Cu}$ ve $2.01 \mathrm{mg}^{100 \mathrm{~g}^{-1} \mathrm{Zn}}$ olarak belirlemişlerdir. Yarılgaç ve ark. (2003), Gevaş yöresinden seçtikleri genotiplerin 100 gram iç meyvesinde $\% 2.08 \mathrm{~N}, 1.20 \mathrm{mg} \mathrm{Cu}, 2.69 \mathrm{mg} \mathrm{Zn}, 90.3$ $\mathrm{mg} \mathrm{Ca}, 124.8 \mathrm{mg} \mathrm{Mg}$ ve $1.76 \mathrm{mg} \mathrm{Mn}$ tespit etmişlerdir. Ayrıca, Tavas yöresi ceviz çalışmasında 100 gram'lık örnekte \% $2.33 \mathrm{~N}, 254 \mathrm{mg} \mathrm{P}, 362.9 \mathrm{mg} \mathrm{K}, 1.11 \mathrm{mg} \mathrm{Cu}$, $2.21 \mathrm{mg} \mathrm{Zn,} 2.46 \mathrm{mg} \mathrm{Fe}, 126.4 \mathrm{mg} \mathrm{Ca}, 100.8 \mathrm{mg} \mathrm{Mg}$, $2.50 \mathrm{mg} \mathrm{Mn}$ ve $1.97 \mathrm{mg} \mathrm{Na}$ olduğunu bildirmişlerdir (Çelik ve ark., 2011).

$\mathrm{Bu}$ çalışmadan elde edilen $\mathrm{P}, \mathrm{K}, \mathrm{Cu}, \mathrm{Zn}, \mathrm{Fe}, \mathrm{Ca}$ ve Mn içerikleri Yarılgaç ve ark. (2003), Muradoğlu ve ark. (2011) ile Çelik ve ark. (2011)'nın sonuçlarından kısmen yüksek bulunmuştur. Ayrıca Tapia ve ark. (2013)'nın dört farklı ceviz çeşidinden elde ettikleri sonuçlarla kıyaslandığında $\mathrm{Mg}$ hariç, diğer bütün mineral madde içerikleri bakımından bariz bir şekilde yüksek sonuçlar elde edildiği saptanmıştır. Mineral madde bakımından farklı sonuçlar elde edilmesinin yetiştirme bölgesinin iklim koşulları, genotiplerin farklı genetik özellikleri, toprak özellikleri, hasat tarihleri ve kültürel işlemler gibi faktörlerden kaynaklanmış olduğu düşünülmektedir (Macrae ve ark., 1993; Caglarirmak, 2003; Ozcan ve ark., 2010).

\section{Sonuç}

Bu çalışmada, Iğdır yöresinden seçilen yerel ceviz genotiplerinde bazı pomolojik ve kimyasal özellikler ile mineral madde içerikleri belirlenmiştir. Çalışmada, incelenen genotiplerden pomolojik ve kimyasal özellikler bakımından önceki çalışmaların bulgularına benzer sonuçlar elde edilirken, özellikle mineral madde içerik değerleri daha yüksek bulunmuştur. Bu sonuçlar; Iğdır yöresi ceviz genotiplerinin beslenmede önemli olan mineral madde içerikleri bakımından değerli olduklarını, bununla birlikte genotip-çevre etkisinin de araştırılması gerektiğini göstermektedir. Çalışmada özellikle kalsiyum (Ca) (76-IĞD-31) ve demir (Fe) (76IĞD-72) bakımından çok zengin ceviz genotiplerin bulunması, Iğdır yöresi ceviz genotiplerin değerini artırmaktadır. Bu değerlerin iyi bakım koşulları altında daha yüksek sonuçlara ulaşması da olası görülmektedir. Besin değeri yüksek olan bu genotiplerin değerlendirilmesi, genetik ilişkilerin belirlenmesi ve yöre ile ilişkili kalite özelliklerinin araştırılması önerilmektedir. 


\section{Teşekkür}

Bu çalışma, 2014-FBE-B07 numaralı proje ile Iğdır Üniversitesi Bilimsel Araştırma Projeleri Koordinasyon Birimi tarafından desteklenmiştir.

\section{Kaynaklar}

Akça, Y., 2001. Ceviz Yetiştiriciliği. Arı Ofset Matbaası, 356s, Tokat.

Andrienko, M.V., Zatokovay, F.T., 1990. Walnut in the Ukrania. Acta Horticulturae, 284: 339-341.

Anonim, 1990. Kabuksuz Ceviz. Türk Standartları Enstitüsü (T.S.E.), TS 1275, Ankara, Türkiye.

Anonim, 1991. Ceviz içi. Türk Standartları Enstitüsü (T.S.E.), TS 1276, Ankara.

Aşkın, M.A., Gün, A., 1995. Çameli ve Bozkurt cevizlerinin (Juglans regia L.) seleksiyon yolu ile 1slahı üzerinde araştırmalar. Türkiye II. Ulusal Bahçe Bitkileri Kong. I. Cilt, Adana, 461-463.

Bakkalbaşı, E., Yılmaz, O.M., Artık, N., 2010. Türkiye'de yetișen bazı ceviz çeşitlerinin fiziksel özellikleri ve kimyasal bileșenleri. Akademik Gıda, 8(1): 6-12.

Bloomhoff, R., Carlsen, M., Andersen, L.F., Jacobs, D.R., 2006. Health benefits of nuts: potential role of antioxidants. British Journal of Nutrition, 96(2): 52-60.

Cemeroğlu, B., 2010. Gida Analizleri. Gida Teknolojisi Derneği Yayınları No: 34, Ankara, 657 s.

Caglarirmak, N., 2003. Biochemical and physical properties of some walnut genotypes (Juglans regia L.). Nahrung/Food, 47(1): 28-32.

Çelik, F., Cimrin, K.M. Kazankaya, A., 2011. Tavas (Denizli) yöresinden selekte edilen ceviz (Juglans regia L.) genotiplerinin bazı fiziksel ve kimyasal özellikleri. Yüzüncü Y1l Üniversitesi Tarım Bilimi Dergisi, 21(1): 4248.

Davis, L., Stonehouse, W., Loots, D.T., Mukuddem-Petersen, J., van der Westhuizen, F., Hanekom, S.J., Jerling, J.C., 2007. The effects of high walnut and cashew nut diets on the antioxidant status of subjects with metabolic syndrome. European Journal of Nutrition, 46: 155-164.

Dogan, M., Akgul, A., 2005. Fatty acid composition of some walnut (Juglans regia L.) cultivars from East Anatolia. Grasasy Aceite, 56(4), 328-331.

FAO, 2012. http://faostat3.fao.org/download/Q/QC/E

Gönül, M., Altuğ, T., Boyacıoğlu, D., Noka, Ü., 1988. Gıda Analizleri. Ege Üni. Müh. Fak. No:64, İzmir, 179s.

James, C.S., 1995. Analytical Chemistry of Foods. Chapman and Hall. $1^{\text {st }}$ ed. London.

Kacar, B., 1972. Bitki ve Toprağın Kimyasal Analizleri. II. Bitki Analizleri Ank. Ünv. Zir. Fak. Yay. 453. Uygulama Kilavuzu, 155, 635 s., Ankara.

Kacar, B., 1984. Bitki Besleme Uygulama Kilavuzu. Ankara Üniversitesi Ziraat Fakültesi Yayınları: 900, Uygulama Kilavuzları: 214, Ankara.

Kapluhan, E., 2015. Ziraat coğrafyası açısından bir inceleme: Kaman İlçesinde (Kırşehir) ceviz üretim faaliyetleri. Marmara Coğrafya Dergisi, 32: 147-170.

Kazankaya, A., Balta, M.F., Yoruk, I.H. Balta, F., Battal, P.İ., 2008. Analysis of sugar composition in nut crops. Asian Journal of Chemistry, 20(2): 1519-1525.

Keleş, H., 2012. Gümüşhacıköy Cevizlerinin (J. regia L.) Seleksiyon Yolu ile Islahı. Yüksek Lisans Tezi, Gaziosmanpaşa Üniversitesi Fen Bilimleri Enstitüsü Bahçe Bitkileri Anabilim Dalı, Tokat.
Korac, M., Crovic, S., Slovic, D., Golosin, B., 1988. Characteristics of Walnut Selections Sampion, Tisa, Backa and Mire. Int. Conf. on Walnuts. Atatürk Cent. H. Res. Inst. Sept. 19-23, Yalova.

Koyuncu, M.A., Așkın, M.A., 1995. Bitlis İli adilcevaz yöresinde seçilmiş ümitvar ceviz tiplerinin bazı bileşim maddelerinin belirlenmesi üzerine bir araştırma. Türkiye II. Ulusal Bahçe Bitkileri Kongresi, Adana, s: 475-478.

Koyuncu, M.A., Aşkın, F., 1999. Van gölü çevresinde yetiştiriciliği yapılan bazı ceviz tiplerinin depolanması üzerine çalıșmalar. Turkish Journal Agriculture and Forestry, 23: 785-796.

Koyuncu, M.M., Ekinci, K., Savran, E., 2004. Cracking characteristics of walnut. Biosystems Engineering, 87(3): 305-311.

Koyuncu, F., Koyuncu, M.A., Erdal, İ., Yaviç, A., 2002. Birkaç ceviz (Juglans regia L.) seleksiyonlarının meyvelerinin kimyasal kompozisyonu. Gida, 27(4): 247251.

Macrae, R., Robinson, R.K., Sadler, M.J., 1993. Encyclopaedia of Food Science. Food Technology and Nutrition, Academic Press INC, San Diego, 3126- 3131.

Mitrovic, M., Ogasanovic, D., Bugarcic, V., Korac, M., 1988. Selection of Walnuts in Yugoslavia and Future Prospects, International Conference on Walnuts, Atatürk Central Horticultural Researche Institue, Yalova-Turkey, 73-78.

Muradoğlu, F., Balta, F., 2010. Ahlat (Bitlis) yöresinden selekte edilen cevizlerin (Juglans regia L.) bazı fiziksel ve kimyasal özellikleri. Yüzüncü Y1l Üniversitesi Tarım Bilimi Dergisi, 20(1): 41-45.

Muradoğlu, F., Gündoğdu, M., Kalan, C., 2011. Bingöl Yöresi ceviz genotiplerinin bazı kimyasal ve mineral içeriklerinin belirlenmesi. Yüzüncü Yıl Üniversitesi Fen Bilimleri Enstitüsü Dergisi, 16(1): 17-21.

Oğuz, H.A., Aşkın, A., 2007. Ermenek yöresi cevizlerinin (Juglans regia L.) seleksiyon yoluyla 1slahı üzerine bir araştırma. Yüzüncü Yıl Üniversitesi, Ziraat Fakültesi, Tarım Bilimleri Dergisi, 17(1): 21-28.

Ozcan, M.M., Iman, C., Arslan, D., 2010. Physico-chemical properties, fatty acid and mineral content of some walnuts (Juglans regia L.) types. Agricultural Sciences, 1(2): 6267.

Ozkan, G., Koyuncu, M.A., 2005. Physical and chemical composition of some walnut (Juglans regia L) genotypes grown in Turkey. Grasas y Aceites, 56(2): 141-146.

Özrenk, K., Kazankaya, A., Balta, M.F., Y1lmaz, M., Muradoğlu, F., 2005, Erzincan'da tohumdan yetiştirilen cevizlerin meyve özelliklerinin tanımlanması. Bahçe Ceviz, 34(1): 133-139.

Polat, M., Okatan, V., Guclu, F., 2015. Determination of some physical and chemical properties of walnut (Juglans regia L.) genotypes grown in the central district of Bitlis/Turkey. Scientific Papers. Series B. Horticulture, LIX, 81-86.

Ros, E., Núñez, I., Pérez-Heras, A., Serra, M., Gilabert, R., Casals, E., Deulofeu, R., 2004. A Walnut Diet Improves Endothelial Function in Hypercholesterolemic Subjects: a Randomized Crossover Trial, 109(13): 1609-1614.

Sharma, S.D., Sharma, O.C., 2004. Studies on the variability in nut characters of seedling trees growing in different locations of himachal pradesh, India, V. International Walnut Symposium, November 9-13, Sorrento (Naples)Italy.

Şahin, İ., 2005. Sağlıklı beslenmede ceviz. Bahçe Ceviz, 34(1): 157-162.

Şen, S.M., 1980. Kuzeydoğu Anadolu ve Doğu Karadeniz 
Bölgesi Cevizlerinin Seleksiyon Yoluyla Islahı Üzerinde Araştırmalar, Atatürk Üniv. Ziraat Fak. Bahçe Bitkileri Bölümü (Doktora Tezi) Erzurum

Şen, S.M., 1986. Ceviz Yetiştiriciliği. Eser Matbaası, Samsun.

Şen, S.M., Karadeniz, T., 2015. The nutritional value of walnut. Journal of Hygienic Engineering and Design, 11: 68-71.

Simsek, M., 2010a. Determination of walnut genotypes with high fruit bearing and quality in Dicle, Hani, Egil and Kocaköy townships. GOU Journal of Agricultural Faculty, 27(1): 85-93.

Simsek, M., 2010b. Selection of walnut types with high fruit bearing and quality in Sanliurfa population. International Journal of the Physical Sciences, 5(7): 992-996.

Simsek, M., 2010c. Physical and chemical properties of superior walnut types in cermik and cungus populations. International Journal of Natural and Engineering Sciences, 4(2): 29-34.

Simsek, M., Yilmaz, K.U., Demirkiran, A.R., 2010. Selection and determination of some significant properties of superior walnut genotypes. Scientific Research and Essays, 5(19): 2987-2996.

Şimşek, M., Osmanoğlu, A., 2010. Mazıdağı (Mardin) yöresindeki doğal cevizlerin (Juglans regia L.) seleksiyonu. YYÜ Tar. Bil. Derg. (YYU J. Agr. Sci.), 20(2): 131-137.
Tapia, M.I. Sanchez-Margado, J.R. Garcia-Parra J., Ramirez, R., Hernandez, T., Gonzales-Games, D., 2013. Comparative study of the nutritional and bioactive compounds content of four walnut (Juglans regia L.) cultivars. Journal of Food Composition and Analysis, 31: 232-237.

Tapsell, L.C., Gillen, L.J., Patch, C.S., Batterham, M., Owen, A., Baré, M., Kennedy, M., 2004. Including Walnuts in a Low-Fat/Modified-Fat Diet Improves HDL cholesterol-tototal cholesterol ratios in patients with type 2 diabetes. Diabetes Care, 27(12): 2777-2783.

Ünver, H., Çelik, M., 2005. Ankara yöresi cevizlerinin (Juglans regia L.) seleksiyon yoluyla 1slah1. 34(1): 83-89.

Vinson, J.A., Cai, Y., 2011. Nuts, especially walnuts, have both antioxidant quantity and efficacy and exhibit significant potential health benefits. Food \& Function, 3(2): $134-40$.

Yarılgaç, T., 1997. Gevaş yöresi cevizlerinin (Juglans regia L.) seleksiyon yoluyla 1slahı üzerinde araştırmalar. Doktora Tezi (Basılmamış), Yüzüncü Y1l Üniversitesi Fen Bilimleri Enstitüsü, Van.

Yarılgaç, T., Özrenk, K., Muradoğlu, F., Tüfenkçi, Ş., 2003. Gevaş yöresinde selekte edilenmiş bazı cevizlerin (Juglans regia L.) pomolojik özellikleri ve makro-mikro element düzeyleri. Yüzüncü Y1l Üniversitesi Ziraat Fakültesi Tarım Bilimleri Dergisi, 13(1): 33-37. 